\title{
PENGARUH KARAKTERISTIK INDIVIDU DAN KOMPETENSI TERHADAP KINERJA USAHA MELALUI KEWIRAUSAHAAN PADA UMKM DI DESA NGUJUNG TOYOMARTO KEC. SINGOSARI KAB. MALANG
}

\author{
Ardelina Putri \\ e-mail : arde putri@yahoo.co.id
}

\begin{abstract}
This research is a quantitative study using a Likert scale. The sample used was a total population of 36 sandal craftsmen. The statistical analysis used is path analysis, using SPSS 17 calculations.

The objectives of this study are: i) To examine the effect of individual characteristics on business performance; ii) Test the effect of individual characteristics on entrepreneurship; iii) Test the effect of competence on business performance; iv) Test the effect of competence on entrepreneurship; v) Test the effect of individual characteristics on business performance through entrepreneurship; vi) Test the effect of competence on business performance through entrepreneurship; vii) Test the effect of entrepreneurship on business performance.

The results showed that: (i) Individual characteristics did not significantly influence business performance; (ii) Individual characteristics do not significantly influence entrepreneurship; (iii) Competence has a significant effect on business performance; (iv) Competence has a significant effect on entrepreneurship; (v) Competence has a significant effect on business performance through entrepreneurship; (vi) Individual characteristics do not significantly influence business performance through entrepreneurship; (vii) Entrepreneurship influences business performance.
\end{abstract}

Keyword: Explanation, quantitative 


\section{PENDAHULUAN}

Usaha Kecil Menengah saat ini memiliki peran yang sangat besar terhadap pembangunan ekonomi di Indonesia, perkembangan jumlah unit usaha kecil menengah yang terus meningkat, tentunya akan dapat membuka lapangan kerja yang besar. Dengan demikian usaha kecil dan menengah merupakan kegiatan usaha yang mampu memperluas lapangan kerja dan memberikan pelayanan ekonomi yang luas pada masyarakat dapat berperan dalam proses pemerataan dan peningkatan pendapatan masyarakat, serta mendorong pertumbuhan ekonomi dan berperan dalam mewujudkan stabilitas nasional pada umumnya dan stabilitas ekonomi pada khususnya. Ketersediaan bahan baku lokal bagi industri kecil dan menengah merupakan keunggulan tersendiri yang memungkinkan dapat beroperasi secara efisien. Pada sisi lain modal kerja yang dibutuhkan relative kecil, sehingga memberi peluang kepada masyarakat yang memiliki jiwa wirausaha untuk mendirikan unit-unit usaha dengan kadar kecanggihan tehnik produksi yang terjangkau. Dalam batas-batas tertentu kegiatan industri kecil dan menengah dapat mengurangi sebagian beban import sehingga dalam kerangka strategis, hal ini dapat menghemat devisa.

Dewasa ini tingkat persaingan dalam dunia usaha menjadi semakin tinggi. Dapat dilihat saat ini usaha sejenis yang muncul semakin banyak. Selaras dengan program pembangunan ekonomi pemerintah indonesia, dimana titik tolak diarahkan pada peningkatan kesejahteraan dan pengentasan kemiskinan melalui pemberdayaan ekonomi rakyat melalui pengembangan wirausaha baru terkait dengan upaya menumbuhkan lingkungan usaha yang kondusif, menumbuhkan kemauan masyarakat untuk berwirausaha, meningkatkan kemampuan masyarakat untuk berwirausaha. Salah satunya pada pengrajin sandal di desa Ngujung Toyomarto Kecamatan Singosari Kabupaten Malang. Namun demikian pengembangan UMKM harus disertai dengan pengembangan SDM (Sumber Daya Manusia) dalam berbagai aspek. Peningkatan kualitas SDM sangat diperlukan terutama di bidang kompetensi SDM seperti knowledge, skill dan ability serta attitude dalam berwirausaha. Pengembangan SDM harus dilakukan tidak hanya kepada UMKM sebagai pemilik usaha, tetapi juga para pekerjanya. Semangat kewirausahaan dan peningkatan produktivitas yang didukung pengembangan teknologi menjadi penting dalam fokus penguatan SDM. Di sisi lain, penggunaan teknologi makin penting mengingat 60 persen proses produksi UMKM masih dilakukan secara sederhana.

Dalam suatu UMKM peran sumber daya manusia memiliki peran yang sangatlah penting. Menurut Abdurrahmat Fathoni dalam Akhmad Subekhi dan Mohammad Jauhar (2012:13) menjelaskan bahwa sumber daya manusia merupakan modal dan kekayaan yang terpenting dari suatu kegiatan manusia. Sumber daya manusia merupakan tokoh sentral dalam organisasi maupun kelompok usaha. Agar aktivitas manajemen berjalan dengan baik, kelompok usaha harus memiliki karyawan yang berpengetahuan dan berketrampilan tinggi serta usaha untuk mengelola usaha seoptimal mungkin sehingga kinerja karyawan meningkat.

Kinerja usaha dapat dilihat dari bagaimana kompetensi dan motivasi individunya. Faktor yang dominan mempengaruhinya adalah kompetensi. Kompetensi yang dimiliki oleh individu karyawan sangat diperlukan dalam rangka meningkatkan kinerja organisasi. Kompetensi berarti 
pengetahuan, sikap dan nilai yang dimiliki dalam bertindak. Adapun pendapat yang dikemukakan oleh Ricky Alamsyah (2009 :25) bahwa kompetensi terdiri dari sejumlah perilaku kunci yang dibutuhkan untuk melaksanakan peran tertentu untuk menghasilkan prestasi atau kinerja yang memuaskan, penentuan kompetensi yang dibutuhkan tentunya akan dapat dijadikan sebagai dasar evaluasi kinerja karyawan. Kompetensi yang belum optimal akan berpengaruh terhadap efisiensi dan efektivitas pekerjaan. Jika kompetensi dalam suatu perusahaan tidak dimiliki oleh para karyawannya kemungkinan tujuan yang ditetapkan tidak dapat dicapai secara efektif dan efisien.

Kompetensi atau kemampuan didefinisikan oleh Mitrani (1995:21) adalah sebagai suatu sifat dasar seseorang yang dengan sendirinya berkaitan dengan pelaksanaan suatu pekerjaan secara efektif atau sangat berhasil (and underlying charactheristic: of an individual which is casually related to effective or superior performance in job), Ketidaksamaan dalam kompetensikompetensi inilah yang membedakan seseorang pelaku unggul dari perilaku yang berprestasi rata-rata. Untuk mencapai kinerja sekedar cukup atau rata-rata, diperlukan kompetensi batas (threshold competemcies) atau kompetemsi essensial. Komptensi batas atau kompetensi istimewa untuk suatu pekerjaan tertentu merupaka pola atau pedoman dalam pemilihan karyawan (personel selection), Perencanaan pengalihan tugas (succestion planing), peniliaian kinerja (performance appaisal), dan pengembangan.

Kompetensi erat kaitannya dengan kinerja, baik kinerja individu maupun kinerja organisasi (perusahaan). Menurut Djaman satori (2007:22) menyebutkan kompetensi berasal dari bahasa inggris competency yang berarti kecakapan, kemampuan dan wewenang. Jadi kompetensi adalah performan yang mengarah pada pencapaian tujuan secara tuntas menuju kondisi yang diinginkannya. Sedangkan kinerja organisasi (perusahaan) didasarkan pada bagaimana manajemen perusahaan merespon kondisi eksternal dan internalnya, yang dengan tolok ukur tertentu akan dapat diketahui berapa tingkat turbelensinya dan berapa tingkat kemampuan untuk mengantisipasinya.

Kompetensi berdasarkan UU No. 13/2003 tentang Ketenagakerjaan: pasal 1 (10), "Kompetensi adalah kemampuan kerja setiap individu yang mencakup aspek pengetahuan, keterampilan dan sikap kerja yang sesuai dengan standar yang ditetapkan".

Menurut Wibowo (2007:110) menyebutkan bahwa kompetensi adalah suatu kemampuan untuk melaksanakan atau melakukan suatu pekerjaan atau tugas yang dilandasi atas keterampilan dan pengetahuan serta didukung oleh sikap kerja yang dituntut oleh pekerjaan tersebut. Dengan demikian, kompetensi menunjukkan keterampilan atau pengetahuan yang dicirikan oleh profesionalisme dalam suatu bidang tertentu sebagai sesuatu yang terpenting, sebagai unggulan bidang tertentu.

Kompetensi yang ada saat ini sangat berpebgaruh pada jiwa kewirausaahan masingmasing individu, dimana sangat berpengaruh untuk mengembangkan usahanya di era milenial ini. Kewirausahaan mengalami perkembangan ilmu dari bidang perdagangan. Perkembangan evolusi kewirausahaan sangat dipengaruhi oleh aspek waktu, dengan perubahan modernitas 
menyebabkan perbedaan sikap wirausaha. Perkembangan evolusi ini kemudian dimanfaatkan oleh perusahaan dan wirausaha sebagai pelaku kewirausahaan.

Kewirausahaan adalah mengidentifikasi, mengembangkan, dan membawa visi tersebut bisa berupa ide inovatif, peluang, cara yang lebih baik dalam menjalankan sesuatu. Hasil akhir dari proses tersebut adalah penciptaan usaha baru yang dibentuk pada kondisi resiko atau ketidakpastian. Diamana Scarborough dan zimmerer dalam Novian (2012) mendefinisikan wirausaha (entrepreneur) yaitu: Wirausaha adalah Orang yang menciptakan suatu bisnis baru dalam menghadapi resiko dan ketidakpastian dengan maksud untuk memperoleh keuntungan dan pertumbuhan dengan cara mengenali peluang dan mengkombinasikan sumber-sumber daya yang diperlukan untuk memanfaatkan peluang tersebut.

Karakteristik individu yang baik dengan jiwa kewirausahaan yang telah kuat, yang didukung adanya kompetensi yang sehat memiliki dampak yang baik untuk kemajuan kinerja usaha terutama sebuah UMKM. Karena kinerja merupakan penampilan hasil karya personel baik kuantitas maupun kualitas dalam suatu proses produksi maupun kerja kelompok personel. Penampilan hasil karya tidak terbatas kepada personel yang memangku jabatan fungsional maupun struktural, tetapi juga kepada keseluruhan jajaran personel di dalam organisasi. Deskripsi dari kinerja menyangkut tiga komponen penting, yaitu: tujuan, ukuran dan penilaian. Penentuan tujuan dari setiap unit organisasi merupakan strategi untuk meningkatkan kinerja. Tujuan ini akan memberi arah dan memengaruhi bagaimana seharusnya perilaku kerja yang diharapkan organisasi terhadap setiap personel. Walaupun demikian, penentuan tujuan saja tidaklah cukup, sebab itu dibutuhkan ukuran, apakah seseorang telah mencapai kinerja yang diharapkan.

Mangkunegara (2000:67) berpendapat "prestasi kerja adalah hasil kerja secara kualitas dan kuantitas yang dicapai oleh seorang karyawan dalam melaksanakan tugasnya sesuai dengan tanggung jawab yang diberikan kepadanya”.

Idealnya kinerja menurut Mitchell dalam Mulyasa, (2005: 125) kinerja dapat ditujukan dalam beberapa criteria yaitu quality of work, promptness, initiative, capability, and communication.

Menurut Notoatmodjo (2009), ada teori yang mengemukakan tentang faktorfaktor yang memengaruhi kinerja yang disingkat menjadi “ACHIEVE” yang artinya Ability (kemampuan yang dapat dikembangkan), Capacity (kemampuan yang sudah tertentukan/terbatas), Help (bantuan untuk terwujudnya performance), Incentive (insentif material maupun non material), Environment (lingkungan tempat kerja karyawan), Validity (pedoman/petunjuk dan uraian tugas), dan Evaluation (adanya umpan balik hasil kerja) jadi kinerja atau performasi dapat diartikan sebagai hasil kerja yang dapat dicapai oleh seseorang atau kelompok orang dalam organisasi, sesuai dengan wewenang dan tanggung jawab masing-masing dalam rangka mencapai tujuan organisasi.

Sejalan dengan pandangan di atas, Baswir (1995) menambahkan bahwa ada 4 faktor penyebab utama rendahnya kinerja usaha kecil dan menengah (UKM) di Indonesia yaitu: 1) Hampir 60\% usaha kecil masih menggunakan teknologi tradisional; 2) Pangsa pasar cendrung 
menurun karena kekurangan modal, lemahnya teknologi dan mansjerial; 3) Sebagian besar usaha kecil tidak mampu memenuhi persyaratan administratif guna memperoleh bantuan dari Bank; 4) Tingkat ketergantungan terhadap fasilitas pemerintah cendrung sangat besar.

Pada organisasi kerja dimana outputnya dapat terindentitifikasi secara individu dalam bentuk kuantitas seperti pabrik rokok, indicator kinerja pekerjanya dapat diukur dengan mudah, yaitu dari besarnya output yang dicapainya dalam kurun waktu tertentu. Namun pada unit kerja kelompok UMKM sandal, kinerja tersebut agak sulit teridentifikasi secara kuantitas secara individual. Dalam hubungan ini (Simamora, 2001:327) Kinerja antara lain dapat dilihat dari indicator-indikator berikut: kepatuhannya terhadap segala aturan yang telah ditetapkan dalam perusahaan, dapat melaksanakan tugasnya tanpa kesalahan (dengan tingkat kesalahan paling rendah), dalam menjalankan tugasnya.

Objektivitas dan sasaran pekerjaan sangat penting, misalnya aktivitas yang dilakukan oleh karyawan harus dapat diidentiikasi berwujud dan dapat dikontrol. Pekerjaan secara formal ditentukan di dalam uraian pekerjaan, rancangan pekerjaan yang meliputi spesifikasi dan aktivitas, metode dan hubungan pekerjaan untuk memenuhi persyaratan kinerja. Rancangan pekerjaan dapat meningkatkan kinerja, mnumbuhkan dan meningkatkan kompetisi individu. Pekerjaan mempunyai nilai motivasi yang lebih besar apabila karyawan diberikan perencanaan dan tanggung jawab yang lebih besar terhadap pekerjaannya dan dapat menumbuhkan jiwa kewirausahaan pada karyawan.

Pelaksanaan pengembangan Kompetensi SDM UMKM diperlukan data kongkrit bagaimana profil Kompetensi SDM UMKM yang kita miliki saat ini dan apakah ada pengaruhnya terhadap kinerja. Oleh karena itu untuk memenuhi data dan informasi konkrit tersebut perlu dilakukan kajian yang mendalam melalui suatu penelitian di bidang ini.

Rumusan masalah berdasarkan latar belakang di atas, yaitu : Apakah terdapat pengaruh karakteristik individu terhadap kinerja usaha ?. Apakah terdapat pengaruh karakteristik individu terhadap kewirausahaan ?. Apakah terdapat pengaruh kompetensi terhadap kinerja usaha ?. Apakah terdapat pengaruh kompetensi terhadap kewirausahaan ?. Apakah terdapat pengaruh karakteristik individu terhadap kinerja usaha melaui kewirausahaan ?. Apakah terdapat pengaruh kompetensi terhadap kinerja usaha melalui kewirausahaan ?. Apah terdapat pengaruh kewirausahaan terhadap kinerja usaha?

Adapun tujuan penelitian berdasarkan rumusan masalah di atas, sebagai berikut : Untuk menguji pengaruh karakteristik individu terhadap kinerja usaha. Untuk menguji pengaruh karakteristik individu terhadap kewirausahaan. Untuk menguji pengaruh kompetensi terhadap kinerja usaha. Untuk menguji pengaruh kompetensi terhadap kewirausahaan. Untuk menguji pengaruh karakteristik individu terhadap kinerja usaha melalui kewirausahaan. Untuk menguji pengaruh kompetensi terhadap kinerja usaha melalui kewirausahaan. Untuk menguji pengaruh kewirausahaan terhadap kinerja usaha. 


\section{METODE PENELITIAN}

\section{Metode Pengumpulan Data}

Metode pengumpulan data yang digunakan adalah

a. Observasi, yaitu pengumpulan data melalui pengamatan langsung dan mencatat informasiinformasi dari data sekunder seperti:

- Keadaan Fisik dan Geografis daerah

- Sentral UMKM yang ada

- Jumlah dan karakteristik UMKM

b. Angket atau kuesioner

Angket atau kuesioner merupakan suatu pengumpulan data dengan memberikan atau menyebarkan daftar pertanyaan/pernyataan kepada responden dngan harapan memberikan respons atas daftar pertanyaan tersebut (Umar,2013:49). Kuesioner ini dilakukan dengan membuat serangkaian pertanyaan yang terkait dengan kompetensi individu pada UMKM sandal di desa Toyomerto Kecamatan Singosari Kab.Malang.

c. Wawancara

Teknik wawancara, menurut Esterberg dalam Sugiyono (2013:231) wawancara merupakan pertemuan dua orang untuk bertukar informasi dan ide melalui tanya jawab, sehingga dapat dikonstruksikan makna dalam suatu topik tertentu. Metode ini digunakan sebagai pelengkap untuk memperoleh data yang tidak dapat dikumpulkan melalui teknik lain, sekaligus sebagai Cross-check terhadap data yang dikumpulkan. Wawancara dilakukan kepada pihak pengusaha sandal sebanyak 36 kelompok pengrajin tentang kondisi atau informasi usahanya.

\section{Jenis dan Sumber Data Penelitian}

Jenis penelitian ini adalah eksplanasi, karena dalam penelitian ini menggunakan dua variabel. Metode eksplanasi adalah suatu metode penelitian yang menggambarkan dua variabel yang diteliti, yaitu variabel bebas dan variabel terikat yang kemudian menjelaskan hubungan atau pengaruh kedua variabel tersebut. Dimana variabel yang ada dalam penelitian ini yaitu Karakteristik individu (X1), Kompetensi (X2), Kewirausahaan (Y1), dan Kinerja Usaha (Y2).

Singarimbun (2003:46) mengatakan mengenai metode eksplanasi yaitu: “Apabila peneliti menjelaskan hubungan atau pengaruh kausal antara variabel-variabel melalui pengujian hipotesis maka dinamakan penelitian penjelasan (Eksplanatory Research)."

Penelitan ini dilakukan pada pengusaha sandal yang berjumlah 36 kelompok pengrajin sandal di desa Ngujung Toyomerto Kecamatan Singosari Kabupaten Malang

Data yang digunakan dalam penelitian ini adalah data primer dan data sekunder. Data primer merupakan berbagai informasi yang diperoleh langsung dari sumber asli (tidak melalui perantara). Data primer adalah data yang didapat dari sumber pertama, baik dari individu atau perseorangan seperti hasil dari wawancara atau hasil pengisian kuesioner yang biasa dilakukan peneliti (Umar,2013:42). Pengumpulan data primer adalah dengan melakukan wawancara secara personal pada koresponden yaitu para pengrajin sandal didesa Ngujung Toyomerto Kecamatan Singosari Kabuoaten Malang. Data sekunder adalah berbagai informasi yang diperoleh peneliti 
secara tidak langsung atau melalui media perantara. Pengumpulan data sekunder dapat berupa laporan tertulis baik berupa buku teori baik berupa jurnal yang ada hubungannya dengan karakteritik individu, kompetensi, kewirausahaan, terhadap kinerja usaha pengrajin sandal di desa Ngujung Toyomerto Kecamatan Singosari Kabupaten Malang.

\section{Pengukuran Variabel}

Skala pengukuran yang digunakan oleh peneliti untuk menyatakan tanggapan dari responden terhadap setiap pertanyaan yang diberikan adalah dengan menggunakan Skala Likert.

Menurut Sugiyono (2004) Skala Likert digunakan untuk mengukur sikap, pendapat, dan persepsi seseorang atau sekelompok orang tentang fenomenasosial. Dalam penelitian fenomenasosial ini telah ditetapkan secaras pesifik oleh peneliti yang selanjutnya disebut sebagaivariabel penelitian, dengan skala Likert, maka variabel yang akan diukur dijabarkan menjadi indikator variabel. Kemudian indikator tersebut dijadikan sebagai titik tolak untuk menyusun item-item instrument yang dapat berupa pernyataan atau pertanyaan. Jawaban setiap item instrumen yang menggunakan skala Likert mempunyai gradasi dari sangat positif sampai negatif yang dapat berupa kata-kata antara lain :
a. Sangat setuju (SS)
: Skor 5
b. Setuju(S)
: Skor 4
c. $\operatorname{Netral}(\mathrm{N})$
: Skor 3
d. Tidak setuju (TS)
: Skor 2
e. Sangat tidak setuju (STS) : Skor 1

\section{Variabel Operasional}

Definisi operasional variabel dalam penelitian pada produksi sandal di desa Ngujung Toyomerto Kecamatan Singosari Kabupaten Malang ini terdiri dari variabel bebas (independent variabel) yaitu Karakteristik Individu $\left(\mathrm{X}_{1}\right)$ dan Kompetensi $\left(\mathrm{X}_{2}\right)$, sedangkan variabel terikat (dependent variable) adalah Kewirausahaan $\left(\mathrm{Y}_{1}\right)$ dan Kinerja Usaha $\left(\mathrm{Y}_{2}\right)$. Berikut definisi dari masing-masing variabel dalam penelitian ini, yaitu :

a. Karakteristik Individu $\left(\mathrm{X}_{1}\right)$

Menurut Rahman (2013:77), karakteristik individu adalah ciri khas yang menunjukkan perbedaan seseorang tentang motivasi, inisiatif, kemampuan untuk tetap tegar menghadapi tugas sampai tuntas atau memecahkan masalah atau bagaimana menyesuaikan perubahan yang terkait erat dengan lingkungan yang mempengaruhi kinerja individu.

Indikator dari karakteristik individu dalam penelitian ini adalah keahlian teknis, kemampuan, pendidikan, keterampilan, sikap, berinteraksi, keyakinan.

b. Kompetensi $\left(\mathrm{X}_{2}\right)$

Menurut Veithzal (2003:298) menyebutkan, kompetensi adalah kecakapan, keterampilan, kemampuan. Kata dasarnya sendiri, yaitu kompeten yang berarti cakap, 
mampu, terampil. Kompetensi mengacu kepada atribut/ karakteristik seseorang yang membuatnya berhasil dalam pekerjaannya.

Indikator dari kompetensi dalam penelitian ini adalah kemampuan mengkonsep produk, mengatur bahan, dan riset pasar.

c. Kewirausahaan $\left(\mathrm{Y}_{1}\right)$

Kewirausahaan, yaitu karakteristik yang melekat pada pelaku UMKM. Pengukuran karakteristik kewirusahaan berdasarkan pendapat Meredith et al. (2000) meliputi percaya diri, berorientasi tugas dan hasil, pengambilan resiko, kepemimpinan, keorisinilan, dan berorientasi masa depan.

Indikator dari kewirausahaan dalam penelitian ini adalah pemahaman produk, peluang bisnis, tanggung jawab, pengalaman.

d. Kinerja Usaha $\left(\mathrm{Y}_{2}\right)$

Menurut Rivai dan Basri dalam Sinambela (2012:6), kinerja adalah hasil atau tingkat keberhasilan seseorang secara keseluruhan selama periode tertentu didalam melaksanakan tugas dibandingkan dengan berbagai kemungkinan, seperti standar hasil kerja, target atau sasaran, atau kriteria yang telah ditentukan terlebih dahulu dan telah disepakati bersama. Indikator kinerja dalam penelitian ini meliputi : pertumbuhan (growth) dan evaluasi.

\section{Metode Analisa Data}

Metode analisis data yang digunakan/dipakai peneliti dalam penelitian ini adalah:

\section{Deskripsi Hasil Survei}

Deskriptif hasil survei dilakukan untuk mendeskripsikan dan menginterpretasikan sesuatu, misalnya kondisi atau hubungan yang ada, pendapat yang berkembang, proses yang sedang berlangsung, akibat atau efek yang terjadi, atau tentang kecendrungan yang tengah berlangsung.

\section{Analisis Kuantitatif}

Untuk mengetahui pengaruh variabel bebas yang terdiri atas Kualitas Individu (X1), Kompetensi (X2), dan variabel terikat yang terdiri atas Kewirausahaan (Y1) dan Kinerja Usaha (Y2), maka analisis data yang digunakan dalam penelitian ini adalah analisis jalur (path analysis). Untuk membantu analisis dalam penelitian ini, penulis menggunakan software IBM SPSS. Persamaan analisis jalur untuk mengetahui pengaruh variabel-variabel di atas dapat dirumuskan sebagai berikut :

$$
\begin{aligned}
& Y_{1}=\beta_{1} X_{1}+\beta_{2} X_{2}+\varepsilon_{1} \\
& Y 2=\beta_{1} X_{1}+\beta_{2} X_{2}+\beta_{3} Y_{1}+\varepsilon_{2}
\end{aligned}
$$

Keterangan:

$\mathrm{Y}_{1} \quad=$ Variabel kewirausahaan

$\mathrm{Y}_{2}=$ Variabel Kinerja Usaha 


$$
\begin{array}{ll}
X_{1} & =\text { Variabel Karakteristik Individu } \\
X_{2} & =\text { Variabel Kompetensi } \\
\beta_{1} & =\text { Koefisien variabel Karakteristik Individu } \\
\beta_{2} & =\text { Koefisien variabel Kompetensi } \\
\beta_{3} & =\text { Koefisien variabel Kewirausahaan } \\
\varepsilon_{1} \text { dan } \varepsilon_{2} & =\text { standar eror }
\end{array}
$$

\section{Koefisien determinasi (R2)}

Koefisien determinasi (R2) digunakan untuk mengukur seberapa besar kemampuan model dalam menerangkan variabel terikat terhadap penelitian ini. Jika R2 semakin besar (mendekati 1), maka dapat dikatakan bahwa varian variabel bebas adalah besar terhadap variabel terikat. Hal ini berarti model yang digunakan semakin kuat untuk menerangkan varian variabel bebas terhadap variabel terikat.

\section{Analisis Jalur}

Analisis jalur yang dikenal sebagai path analysis dikembangkan pertama tahun 1920-an oleh seorang ahli genetika yaitu Sewall Wright (Riduwan \& Engkos, 2012:1). Analisis jalur diartikan oleh Bohrnstedt (Riduwan \& Engkos, 2012:1) bahwa 'a technique for estimating the effect's a set of independent variables has on a dependent variabel from a set of observed correlations, given a set of hypothesized causal asymmetric relation among the variables.'

Analisis jalur adalah bagian dari model regresi yang dapat digunakan untuk menganalisis hubungan sebab akibat antar satu variabel dengan variabel lainnya. Sistem hubungan sebab akibat tersebut menmyangkut dua jenis variabel yaitu variabel bebas atau yang lebuh dikenal dengan variabel eksogen yang biasa disimbolkan dengan huruf $\mathrm{X}_{1}, \mathrm{X}_{2}, \ldots \mathrm{X}_{\mathrm{m}}$ dan variabel terikat atau variabel yang dipengaruhi, yang dikenal dengan variabel endogen yang biasa dsimbolkan dengan huruf $\mathrm{Y}_{1}, \mathrm{Y}_{2}, \ldots, \mathrm{Y}_{\mathrm{n}}$. Sedangkan tujuan utama dari analisi jalur adalah 'a method of measuring the direct influence along each separate path ini such a sytem and thus of finding the degree to wich variation of a given effect is determined by each particular cause. The method depend on the combination of knowledge of the degree of correlation among the variables in a system with such knowledge as may possessed of the causal relations (Maruyama, Riduwan \& Engkos, 2012:1)

Dalam analisis jalur pengaruh variabel eksogen terhadap variabel endogen dapat berupa pengaruh langsung dan tidak langsung (direct \& indirect effect), atau dengan kata lain analisis jalur memperhitungkan adanya pengaruh langsugn dan tidak langsung. Berbeda dengan model regresi biasa dimana pengaruh variabel independen terhadap variabel dependen hanya berbentuk pengaruh langsung.

Pengaruh tidak langsung suatu variabel eksogen terhadap variabel endogen adalah melalui variabel lain yang disebut variabel antara (intervening variable). Sebagai contoh dalam riset pemasaran, pengaruh variabel bauran penjualan terhadap variabel loyalitas pelanggan bukan 
hanya secara langsung tetapi secara tidak langsung melalui variabel lain seperti variabel ekuitas merek.

Selain itu analisis jalur merupakan suatu metode yang digunakan pada model kausal yang telah dirumuskan peneliti atas dasar pertimbangan-pertimbangan teoritis dan pengetahuan tertentu. Dengan kata lain analisis jalur memiliki kegunann untuk mencek atau menguji model kausal yang diteorikan dan bukan menurunkan teori kausal tersebut (Sujana, 2003:293).

Penggunaan analisis jalur dalam analisis sata penelitian didasarkan pada beberapa asumsi berikut :

1. Pada model analisis jalur, hubungan antar variabel adalah bersifat linier adaptif dan bersifat normal,

2. Hanya system aliran kausal ke satu arah, artinya tidak ada arah kausalitas yang berbalik,

3. Variabel terikat (endogen) minimal dalam skala ukur interval dan rasio,

4. Menggunakan sampel probability sampling, yaitu teknik pengambilan sampel untuk memberikan peluang yang sama pada setiap anggota populasi untuk dipilih menjadi anggota sampel,

5. Observed variables diukur tanpa kesalahan (instrument pengukuran valid dan reliable) artinya variabel yang diteliti dapat diobservasi secara langsung, dan

6. Model yang dianalisis dispesifikasikan (diidenifikasi) dengan benar berdasarkan teori-teori dan konsep-konsep yang relevan, artinya model teori yang dikaji atau diuji dibangun berdasarkan kerangka teoritis tertentu yang mampu menjelaskan hubungan kausalitas antar variabel yang diteliti.

\section{HASIL PENELITIAN DAN PEMBAHASAN}

\section{Hasil Analisis Jalur}

Pada penelitian ini analisis yang di gunakan untuk menguji hipotesis yang telah digunakan adalah antar variabel yang dihipotesiskan dengan menggunakan analisis jalur (path analysis). Analisis ini digunakan untuk mengethaui tingkat pengaruh suatu hubungan kausal yang dilakukan dari hasil penyebaran kuesioner. Perhitungan koefisien path pada penelitian ini menggggunakan analisis regresiii standardize dengan melihat sevara parsial pada masing-masing persamaan dengan mengunakan software SPSS versi 17 . Hasilnya adalah sebagai berikut:

\section{Pengaruh Pengaruh Karakteristik Individu $\left(\mathbf{X}_{1}\right)$, Kompetensi $\left(\mathbf{X}_{2}\right)$ Terhadap Kewirausahaan $\left(\mathbf{Y}_{1}\right)$}

Hasil uji regresi standardize Pengaruh Karakteristik Individu $\left(\mathrm{X}_{1}\right)$, Kompetensi $\left(\mathrm{X}_{2}\right)$ Terhadap Kewirausahaan ( $\left.\mathrm{Y}_{1}\right)$ adalah sebagai berikut :

\section{Tabel 1 Hasil Uji Koefisien Jalur Pengaruh Karakteristik Individu $\left(\mathbf{X}_{1}\right)$, Kompetensi $\left(\mathbf{X}_{2}\right)$} Terhadap Kewirausahaan ( $\left.\mathbf{Y}_{1}\right)$ 


\begin{tabular}{|l|c|c|c|c|}
\hline \multicolumn{1}{|c|}{ Variabel } & Beta & $\mathrm{T}_{\text {hitung }}$ & PV/Prob & Sig T \\
\hline Karakteristik Individu $\left(\mathrm{X}_{1}\right)$ & 0.072 & 0.903 & 0,05 & 0.339 \\
\hline Kompetensi $\left(\mathrm{X}_{2}\right)$ & 0.998 & 12.535 & 0,05 & 0.000 \\
\hline $\mathrm{R} \quad=0.937$ & $=0.875$ \\
\hline R Square $=191.426$ & \\
\hline $\mathrm{F}$ & $=0.000$ \\
\hline Sig. F
\end{tabular}

Sumber : Data Primer diolah, Tahun 2019

Sehingga diperoleh persamaan regresi untuk variabel yang dianlisis dalam penelitian ini yaitu :

$\mathrm{Y}_{1}=\beta_{1} \mathrm{X}_{1}+\beta_{2} \mathrm{X}_{2}$

$\mathrm{Y}_{1}=0,086 \mathrm{X}_{1}+0,888 \mathrm{X}_{2}$

Dari persamaan regresi linier berganda tersebut, dapat diuraikan sebagai berikut :

a. Besarnya koefisien regresi variabel Karakteristik Individu sebesar 0,072 menunjukkan bahwa variabel Karakteristik Individu mempunyai pengaruh positif terhadap Kewirausahaan.

b. Besarnya koefisien regresi variabel Kompetensi sebesar 0,998 menunjukkan bahwa variabel Kompetensi mempunyai pengaruh positif terhadap Kewirausahaan.

2. Pengaruh Karakteristik Individu $\left(\mathrm{X}_{1}\right)$, Kompetensi $\left(\mathrm{X}_{2}\right)$ Terhadap Kewirausahaan $\left(\mathrm{Y}_{1}\right)$ Melalui Kinerja Usaha ( $\left.\mathbf{Y}_{2}\right)$

Hasil uji regresi standardize Pengaruh Karakteristik Individu $\left(\mathrm{X}_{1}\right)$, Kompetensi $\left(\mathrm{X}_{2}\right)$ Terhadap Kewirausahaan ( $\left.\mathrm{Y}_{1}\right)$ Melalui Kinerja Usaha $\left(\mathrm{Y}_{2}\right)$ adalah sebagai berikut :

Tabel 2 Hasil Uji Koefisien Jalur Pengaruh Karakteristik Individu $\left(\mathbf{X}_{1}\right)$, Kompetensi $\left(\mathbf{X}_{2}\right)$

Terhadap Kewirausahaan ( $\left.\mathbf{Y}_{1}\right)$ Melalui Kinerja Usaha ( $\left.\mathbf{Y}_{2}\right)$

\begin{tabular}{|c|c|c|c|c|}
\hline Variabel & Beta & $\mathrm{T}_{\text {hitung }}$ & PV/Prob & Sig \\
\hline Karakteristik Individu $\left(\mathrm{X}_{1}\right)$ & -0.012 & -0.248 & 0.05 & 0.805 \\
\hline Kompetensi $\left(\mathrm{X}_{2}\right)$ & 0.679 & 12.231 & 0.05 & 0.000 \\
\hline Kewirausahaan $\left(\mathrm{Y}_{1}\right)$ & 0.395 & 7.812 & 0.05 & 0.000 \\
\hline $\mathrm{R}=0.978$ & & & & \\
\hline R Square & & & & \\
\hline$=805.807$ & & & & \\
\hline$=0.000$ & & & & \\
\hline
\end{tabular}

Sumber : Data Primer diolah, Tahun 2019

Sehingga diperoleh persamaan regresi untuk variabel yang dianlisis dalam penelitian ini yaitu :

$Y_{2}=\beta_{1} X_{1}+\beta_{2} X_{2}+\beta_{3} Y_{1+} €_{2}$

$\mathrm{Y}_{2}=-0,011 \mathrm{X}_{1}+0,649 \mathrm{X}_{2}+0,381 \mathrm{Y}_{1}$

Dari persamaan regresi linier berganda tersebut, dapat diuraikan sebagai berikut : 
a. Besarnya koefisien regresi variabel Karakteristik Individu sebesar -0,012 menunjukkan bahwa variabel Karakteristik Individu mempunyai pengaruh negatif terhadap Kinerja Usaha.

b. Besarnya koefisien regresi variabel Kompetensi sebesar 0,679 menunjukkan bahwa variabel Pengawasan mempunyai pengaruh positif terhadap Kinerja Usaha.

c. Besarnya koefisien regresi variabel Kewirausahaan sebesar 0,395 menunjukkan bahwa variabel Kewirausahaan mempunyai pengaruh positif terhadap kinerja.

\section{KESIMPULAN DAN SARAN}

Kesimpulan

Berdasarakan permasalahan dan pembahasan tentang Pengaruh Karakteristik Individu Dan Kompetensi Terhadap Kinerja Usaha Melalui Kewirausahaan Pada Umkm Sandal Di Desa Ngujung Toyomarto Kec. Singosari Kab. Malang, maka dapat ditarik kesimpulan sebagai berikut :

1. Karakteristik Individu tidak berpengaruh signifikan terhadap kinerja usaha.

2. Karakteristik Individu tidak berpengaruh signifikan terhadap kewirausahaan.

3. Kompetensi berpengaruh signifikan terhadap kinerja usaha.

4. Kompetensi berpengaruh signifikan terhadap kewirausahaan

5. Kompetensi berpengaruh signifikan terhadap kinerja usaha melalui kewirausahaan.

6. Karakteristik individu tidak berpengaruh signifikan terhadap kinerja usaha melalui kewirausahaan.

7. Kewirausahaan berpengaruh terhadap kinerja usaha

\section{Saran Dan Implikasi}

Berdasarkan hasil penelitian ini, peneliti dapat mengemukakan saran yang diharapkan dapat memberikan manfaat.

1. Memberikan peningkatan kualitas pengetahuan SDM pelaku usaha yang ada dengan pelatihan-pelatihan penunjang baik teknis, fungsional atau struktural juga workshop pendukung kinerja. Hal ini juga akan meningkatkan kemampuan dalam perumusan masalah serta pengambilan keputusan yang lebih baik.

2. Pelaku usaha harus dapat melaksanakan tugas dan perannya dengan baik dan secara efisien untuk meningkatkan penjualan.

3. Perlu adanya komunikasi antar pelaku usaha satu dengan yang lainnya

4. Perlu adanya pelatihan atau arahan bagi UMKM sandal saat ini karena masih terdapat keraguan dalam menanggapi pertumbuhan penjualan yang berkelanjutan, pertumbuhan usahayang stabil, pertumbuhan jumalh tenaga kerja, pertumbuhan laba, kedisiplinan, sangat dibutuhkan untung menunjang kinerja usaha. Perlu adanya inovasi dan kreatifitas serta semangat juang tinggi untuk bisa bertahan dan berkambang usahanya.

\section{Keterbatasan Penelitian}


Penelitian ini hanya mengukur variabel Karakteristik Individu dan Kompetensi. Sedangkan untuk meningkatkan motivasi kerja dan kinerja usaha masih banyak variabel lain yang mempengaruhinya, seperti tingkat kualitas dan komitmen organisasional. Untuk itu, diharapkan pada peneliti selanjutnya dapat menambahkan dan meneliti variabel yang lain.

Selain itu juga, tidak semua koresponden menjawab kuisioner dengan baik, jadi mengharusnya peneliti mewawancara dan mengambil kesimpulan dari beberapa pertanyaan yang telah di ajukan. Faktor yang mempengaruhinya tersebut dengan adanya kesibukan proses produksi, dan tingkat pendidikan para pengrajin yang masih sangat terbatas.

\section{DAFTAR PUSTAKA}

Amage, N., Rinthaisong, I., \& Songsom, A. 2014. Factors Influencing to Behavioral Competency for Competitiveness and Success of Thai - Malaysia Border Trade Entrepreneurs to Suport AEC. Journal of Management Research, 6 (2), 221-231.

Amin, Shobikin. 2017 . Pengaruh Karakteristik Individu, Sikap dan Persepsi terhadap Perilaku Kewirausahaan (Studi Pada Industri Kecil Kerajinan Tangan dan Handycraft di Kabupaten Lamongan). Media Mahardika Vol.15 No.3 Mei 2017

Ardiana, I.D.K.R. , I.A. Brahmayanti, Subaedi . 2010 . Kompetensi SDM UKM dan Pengaruhnya Terhadap Kinerja UKM di Surabaya. Jurnal Manajemen dan Kewirausahaan, Vol.12, No.1, Maret $2010: 42-55$

Bungin, Burhan. 2013. Metodologi Penelitian Kuantitatif : Komunikasi, Ekonomi, dan Kebijakan Publik Serta Ilmu-Ilmu Sosial Lainnya. Edisi Kedua. Cetakan Ketujuh. Kencana Prenada Media Group. Jakarta.

Dhamayantie , Endang, Rizky Fauzan. 2017 . Penguatan Karakteristik dan Kompetensi Kewirausahaan untuk meningkatkan kinerja UMKM. Matrik : Jurnal Manajemen, Strategi Bisnis dan Kewirausahaan Vol. 11, No. 1, Februari 2017

Dhermawan, Anak Agung Ngurah Bagus, I Gde Adnyana Sudibya, I Wayan Mudiartha Utama . 2012 . Pengaruh Motivasi, Lingkungan Kerja, Kompetensi, Dan Kompensasi Terhadap Kepuasan Kerja Dan Kinerja Pegawai Di Lingkungan Kantor Dinas Pekerjaan Umum Provinsi Bali. Jurnal Manajemen, Strategi Bisnis, dan Kewirausahaan Vol. 6, No. 2 Agustus 2012

Fadholi, Muhammad Reza, Mochammad Amien Gunadi . 2013 . Pengaruh Karakteristik Pribadi Wirausahawan Pada Kinerja Usaha Dengan Orientasi Pasar Sebagai Variabel Pemediasi: Studi Pada UKM Fotokopi, Rental Komputer Dan Warnet Di Kota Surakarta. Focus Manajerial Vol.12, No.1 , $2013: 1-11$ 